improving nuclear safety technology, and for building a deep geological repository in Siberia to dispose of the nuclear waste.

The project, which requires approval from both the US and Russian governments, is conditional on Russia agreeing not to engage in commercial reprocessing activities for 30 years.

"Such a scheme would be beneficial to Russia and to the rest of the world," says Cochran. But Minatom seems unwilling to make the concessions required, he says.

Environmentalists are unhappy with both plans. Majak and Krasnojarsk are among the most polluted spots on Earth, says Tobias Münchmeyer, a nuclear campaigner at Greenpeace International. "It would be cynical to use these ecological disaster areas as dumping grounds for foreign nuclear waste."

Vladimir Slivyak, co-chairman of Ecodefense, a network of environmental groups in Russia, says that Minatom would find ways to ignore or alter any international agreement, he says. "Whoever thinks that Minatom can be influenced by foreign powers is either money-driven or naive," he says. "If waste gets into Russia you can bet that it will be reprocessed and that plutonium will be separated."

\title{
GM cows face slaughter in multiple sclerosis experiment
}

Bob Brockie, Wellington, New Zealand

The New Zealand High Court has granted a stay of execution on its ruling to slaughter a small herd of cows pregnant with genetically modified calves.

The unborn calves are part of a programme aimed at developing a treatment for multiple sclerosis. Researchers at life-sciences company AgResearch have inserted the gene for human myelin basic protein into the

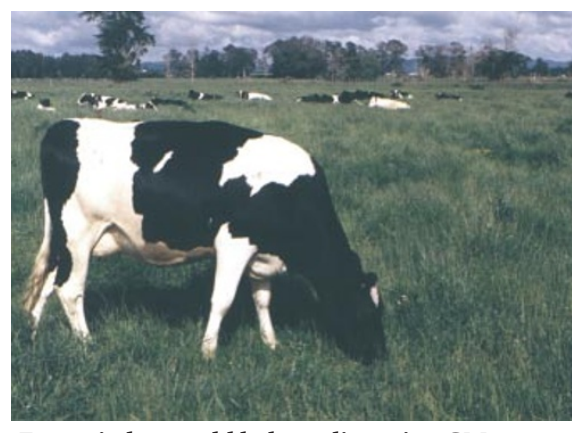

Errors in law could halt studies using GM cows. embryos in the hope of producing high levels of the protein in the cattle's milk. They hope to use the protein to develop therapies for multiple sclerosis.

The Environmental Risk Management Authority (ERMA), the statutory body that vets any genetic engineering in New Zealand, approved the experiments last year. But activists and Maoris challenged the approval and the High Court ruled, for a second time, that the experiment must stop.

The court did not question the science behind the research but ruled that ERMA made errors of law in its approval process. ERMA has a week to reconsider its approval and to present details of its decision to the court, or the experiment must stop. If ERMA fails, the cattle will be slaughtered on 28 May.

The Green Party, which opposes any form of genetic modification, is calling for the immediate slaughter of the cows. The head of the research programme, Phil L'Hullier, frustrated at the delays, recently resigned to pursue similar work in Australia.

\section{Individual genomes targeted in sequencing revolution}

\section{David Adam, London}

A Cambridge biotech start-up company is developing new technology that it claims could allow an individual's genome to be sequenced in just a few days - at a fraction of the cost of existing technology.

Strong claims indeed - today's highestthroughput sequencing labs currently take months to sequence a mammalian genome completely. But Solexa, which opened its new laboratories earlier this month, may have the scientific muscle to back up such claims. Three members of the company's scientific advisory board hold top positions at the nearby Sanger Centre, which decoded around a third of the human genome.

Solexa hopes its technology will help to identify the complex associations between disease and the sites of genetic variability, called single nucleotide polymorphisms (SNPs), which are scattered through the genome. SNPs are time-consuming and expensive to locate in just one individual, never mind in the tens of thousands of patients and controls that would be needed for large-scale studies of such associations.

"It's a numbers game and nothing around at the moment gets anywhere close to being powerful enough to do those kind of genome-wide association studies," says Nick McCooke, Solexa's president and managing director.

Solexa is also some way off that goal, McCooke admits. But he claims that within two years his company could produce a working prototype that would have "the sequencing capacity of 20 Sanger Centres". He says comparing the full sequence of a genome is the best way to sift through individuals to identify the crucial genetic differences, including SNPs.

At the heart of the new technology, which is still to be finalized and scaled up, are what the company terms 'single-molecule arrays'. The single-stranded DNA samples to be sequenced, comprising strings of the four nucleotides adenosine $(\mathrm{A})$, cytosine $(\mathrm{C})$, guanine $(\mathrm{G})$ and thymidine $(\mathrm{T})$, are first immobilized onto a surface through a synthetic sequence of 'primer' DNA. Solexa says it will produce chips that can hold up to 100 million immobilized samples.

The surface is sequentially washed with solutions containing a single type of nucleotide - tagged with a fluorescent marker - and a DNA polymerase enzyme. The enzyme tries to build the complementary strand - A binding with $\mathrm{T}$, and $\mathrm{G}$ binding with $\mathrm{C}$ - starting at the primer sequence. After each wash, a laser scanner identifies which strands have gained complementary nucleotides. The fluorescent tags are then chemically removed and the process is repeated. The complementary strands thus build up one nucleotide at a time, so analysis is simple.

In this way, each of the 100 million immobilized DNA samples acts like a sequencing lane in a conventional machine. And because the technique requires no initial amplification of the samples and very small quantities of reagents, McCooke says it will be far cheaper than existing technology.

Solexa is not the only company working on such sequencing techniques. Amersham Pharmacia Biotech, for example, says it is developing a single-molecule array technique that is "similar in scope". www.solexa.co.uk

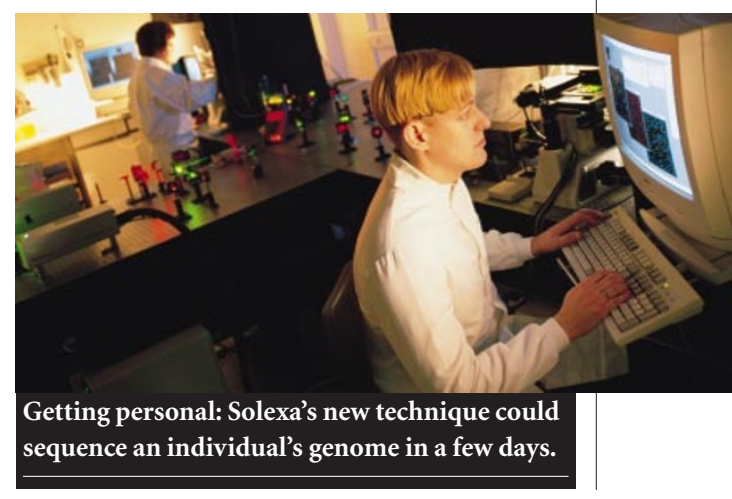

